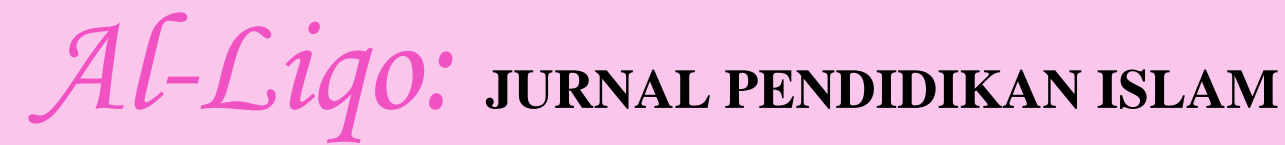 \\ P-ISSN: 2461-033X | E-ISSN: 2715-4556
}

\section{Upaya Guru Pendidikan Agama Islam dalam Meningkatkan Pemahaman Keagamaan Siswa}

\author{
*Jafri Jafri ${ }^{1)}$ \\ Email: $\underline{\text { smajafri1234@gmail.com }}{ }^{1}$ \\ ${ }^{1)}$ SMA I Negeri Tembilahan Indragiri Hilir, Riau, Indonesia
}

\begin{abstract}
This study aimed to determine the efforts of Islamic Religious Education teachers in improving students' religious understanding at SMA Negeri 1 Tembilahan. The approach in this study was a descriptive qualitative approach using observation, interviews, and documentation. Data analysis techniques were data reduction, data presentation, and data verification while checking the validity of the data was expanded participation, observing accuracy, triangulation, and expert consultation. The results showed that teachers had implemented well except for the lack of infrastructure and learning time in optimizing students' religious understanding. Based on this research, the practical implications were used as material to assist teachers in optimizing and new knowledge for teachers so that teachers can improve students' religious understanding.
\end{abstract}

Keywords: Teachers' efforts, Religious understanding, Students

\begin{abstract}
Abstrak
Penelitian ini bertujuan untuk mengetahui upaya guru Pendidikan Agama Islam dalam meningkatkan pemahaman beragama siswa di SMA Negeri 1 Tembilahan. Pendekatan dalam penelitian ini adalah pendekatan kualitatif deskriptif dengan menggunakan metode pengumpulan data observasi, wawancara dan dokumentasi. Teknik analisis data meliputi reduksi data, penyajian data dan verifikasi data, sedangkan pengecekan keabsahan data dilakukan dengan memperluas partisipasi, pengamatan ketelitian, triangulasi dan konsultasi ahli. Hasil penelitian menunjukkan telah dilaksanakan dengan baik kecuali kurangnya ketersediaan sarana prasarana dan waktu pembelajaran dalam mengoptimalkan pemahaman agama siswa. Berdasarkan penelitian ini implikasi praktis digunakan sebagai bahan untuk membantu guru dalam memahami dan pengetahuan baru bagi guru sehingga guru dapat meningkatkan pemahaman agama siswa.
\end{abstract}

Kata Kunci: Upaya Guru, Pemahaman Agama, Siswa

\section{Cara Mensitasi Artikel:}

Jafri, J. (2021). Upaya guru pendidikan agama Islam dalam meningkatkan pemahaman keagamaan siswa. Al-Liqo: Jurnal Pendidikan Islam, 6(1), 10-33. https://doi.org/10.46963/alliqo.v6i1.331.

\section{*Corresponding Author: \\ smajafri1234@gmail.com}

Editorial Address: Kampus Parit Enam, STAI

Auliaurrasyidin Tembilahan. Jl. Gerilya No. 12

Tembilahan Barat, Riau Indonesia 29213.

\section{Histori Artikel:}

$\begin{array}{ll}\text { Diterima } & : 29 / 05 / 2021 \\ \text { Direvisi } & : 30 / 06 / 2021 \\ \text { Diterbitkan } & : 30 / 06 / 2021\end{array}$




\section{PENDAHULUAN}

Keyakinan terhadap agama dan keterlibatan dalam kegiatan agama merupakan salah satu instrumen positif dalam perkembangan remaja. Selain itu, keyakinan terhadap agama di masa remaja merupakan fondasi bagi kematangan beragama di masa dewasa. Masa remaja menurut teori psikoanalisis disebut sebagai masa pencarian identitas yang ditandai dengan keraguan dan pertanyaan terhadap konsep-konsep yang telah diterima pada masa anak-anak, termasuk keyakinan agama. Keyakinan agama merupakan hasil interaksi antara kekuatan eksternal dengan interpretasi terhadap segala kejadian di sepanjang rentang kehidupan. Di masa awal kehidupan, keyakinan agama dipengaruhi oleh proses sosialisasi nilai agama dari orang tua dan keluarga. Memasuki masa remaja, interaksi remaja dengan institusi di luar lingkungan keluarga juga mempengaruhi keyakinan remaja terhadap agama.

Secara formal, remaja mempelajari agama melalui institusi pendidikan, seperti sekolah. Sekarang ini terdapat kecenderungan untuk menyekolahkan anak di sekolah berbasis agama, selain mendapatkan pelajaran agama di sekolah, siswa juga mendapatkan pengetahuan agama melalui guru pendidikan agama Islam yang secara profesional mendidik, mengajar, membimbing, mengarahkan, melatih, menilai dan mengevaluasi peserta didik melalui kegiatan keagamaan. Guru sebagai pengganti orang tua di sekolah mempunyai peran yang sangat penting dalam upaya memberikan pemahaman keagamaan bagi peserta didik. Guru merupakan figur sentral dalam menyelenggarakan pendidikan, karena guru adalah sosok yang diperlukan untuk memacu keberhasilan peserta didiknya.

Zakiah Darajat (2009: 39) menguraikan bahwa seorang guru adalah pendidik profesional, karenanya secara implisit ia telah merelakan dirinya menerima dan memikul sebagian tanggung jawab pendidikan yang terpikul di pundak para orang tua. Mereka ini, tatkala menyerahkan anaknya ke sekolah, sekaligus berarti pelimpahan sebagian tanggung jawab pendidikan anaknya kepada guru. Hal itu pun menunjukkan pula bahwa orang tua tidak mungkin menyerahkan anaknya kepada sembarang guru/sekolah karena tidak sembarang orang dapat menjabat sebagai guru. 
Sedangkan guru pendidikan agama Islam adalah seorang pendidik yang mengajarkan ajaran Islam dan membimbing anak didik ke arah pencapaian kedewasaan serta membentuk kepribadian muslim yang berakhlak sehingga terjadi keseimbangan kebahagiaan di dunia dan akhirat. (Zuhairini, 1994: 45).

Ahmad Tafsir (2002: 76) mengutip pendapat Al-Ghazali yang mengatakan bahwa siapa yang memilih pekerjaan mengajar, ia sesungguhnya telah memilih pekerjaan besar dan penting. Kedudukan guru pendidikan agama Islam yang demikian tinggi dalam Islam dan merupakan realisasi dari ajaran Islam itu sendiri, maka pekerjaan atau profesi sebagai guru agama Islam tidak kalah pentingnya dengan guru yang mengajar pendidikan umum.

Tujuan pendidikan tersebut dapat diwujudkan melalui proses pendidikan baik di sekolah, keluarga dan masyarakat. Pendidikan adalah usaha sadar yang dilakukan oleh keluarga, masyarakat dan pemerintah, melalui kegiatan bimbingan, pengajaran, dan latihan, yang berlangsung di sekolah dan di luar sekolah sepanjang hayat. Pendidikan bertujuan untuk mempersiapkan peserta didik agar dapat memainkan peranan dalam berbagai lingkungan hidup secara tepat di masa yang akan datang. Pendidikan merupakan pengalaman belajar terprogram dalam bentuk pendidikan formal, non formal, dan informal di sekolah ataupun di luar sekolah dengan tujuan untuk mengoptimalkan perkembangan kemampuan individu. Hal ini dipertegas dalam QS. Al- Mujadilah: 11.

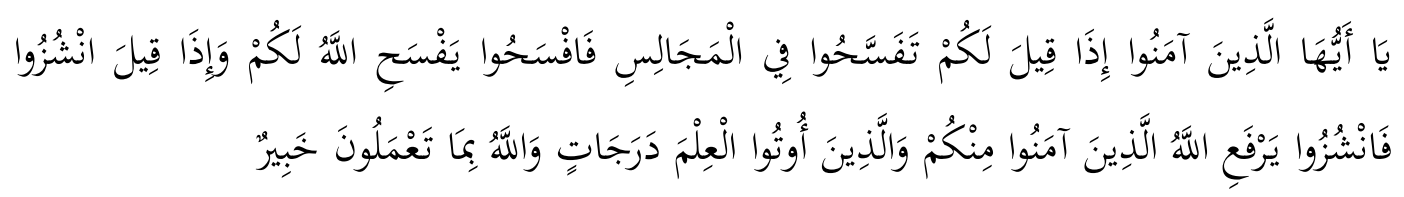

Artinya: Hai orang-orang beriman apabila kamu dikatakan kepadamu: "Berlapang-lapanglah dalam majelis", Maka lapangkanlah niscaya Allah akan memberi kelapangan untukmu. dan apabila dikatakan: "Berdirilah kamu", Maka berdirilah, niscaya Allah akan meninggikan orang-orang yang beriman di antaramu dan orang-orang yang diberi ilmu pengetahuan beberapa derajat. dan Allah Maha mengetahui apa yang kamu kerjakan (Q.S. Al-Mujadilah: 11).

Dari ayat di atas dapat dipahami bahwa orang-orang beriman dan berilmu serta ilmunya itu diamalkan sesuai dengan yang diperintahkan Allah SWT. menegaskan bahwa Dia Maha Mengetahui semua yang dilakukan manusia, tidak 
ada yang tersembunyi bagi-Nya. Dia akan memberikan balasan yang adil, sesuai dengan perbuatan yang dilakukannya. Perbuatan baik akan dibalas dengan surga dan perbuatan buruk dan terlarang akan dibalas dengan azab neraka. Ini berarti kebutuhan akan pendidikan merupakan suatu hal yang tidak bisa dipungkiri, bahkan semua itu merupakan hak semua warga negara. Berkenaan dengan ini, dalam Udang-undang Dasar 45 Pasal 31 ayat (1) secara tegas disebutkan bahwa: Tiap-tiap warga Negara berhak mendapat pengajaran. Tujuan pendidikan nasional dalam Undang-undang Republik Indonesia No. 20 tahun 2003 tentang Sistem Pendidikan Nasional Pasal 3 adalah Mengembangkan potensi peserta didik agar menjadi manusia yang beriman dan bertakwa yang Tuhan Yang Maha Esa, berakhlak mulia, sehat, berilmu, cakap, kreatif, mandiri dan menjadi warga Negara yang demokratis serta bertanggung jawab. (Republik Indonesia, 2003: 5).

Pendidikan agama merupakan salah satu dari tiga subyek pelajaran yang harus dimasukkan dalam kurikulum setiap lembaga pendidikan formal di Indonesia. Hal ini karena kehidupan beragama merupakan salah satu dimensi kehidupan yang diharapkan dapat terwujud secara terpadu. (Chabib Thoha, dkk, 2009: 3).

Pendidikan agama adalah pendidikan yang memberikan pengetahuan dan membentuk sikap, kepribadian, dan keterampilan peserta didik dalam mengamalkan ajaran agamanya, yang dilaksanakan sekurang-kurangnya melalui mata pelajaran/kuliah pada semua jalur, jenjang, dan jenis pendidikan. Jadi Pendidikan Agama Islam adalah upaya sadar dan terencana dalam menyiapkan peserta didik untuk mengenal, memahami, menghayati, mengimani, bertakwa, berakhlak mulia, mengamalkan ajaran agama Islam dari sumber utamanya kitab suci Al-Quran dan Al-Hadits melalui kegiatan bimbingan, pengajaran, latihan, serta penggunaan pengalaman.

Pendidikan agama pada anak akan memberikan nilai positif bagi perkembangan anak, sekiranya dengan pendidikan agama tersebut, pola perilaku anak akan terkontrol oleh aturan-aturan yang telah ditetapkan oleh agama dan dapat menyelamatkan anak agar tidak terjerumus dalam jurang kenistaan dan pergaulan bebas yang pada akhirnya akan merusak masa depan anak. Dengan adanya pendidikan agama yang diberikan kepada peserta didik, hal ini merupakan salah 
satu cara untuk membentuk perilaku keagamaannya. Perilaku keagamaan tersebut merupakan perbuatan atau tindakan yang berdasarkan nilai-nilai agama yang telah ditentukan oleh agama. Perilaku keagamaan ini tidak timbul tanpa adanya hal yang memengaruhinya, baik faktor internal maupun faktor eksternal.

Untuk dapat mencapai tujuan tersebut, salah satu kebijakan yang diambil oleh pemerintah adalah pelajaran agama diberi alokasi waktu 3 x 45 menit dalam setiap minggunya bahkan setiap pembelajaran, baik pelajaran agama ataupun pelajaran umum, guru wajib mengajarkan nilai-nilai spiritual dan sosial yang merupakan manifestasi dari ketaatan beragama, Kemendikbud juga mengeluarkan kebijakan Full Day School yang disusul dengan perpres tentang pendidikan karakter. Sehingga guru sebagai penanggung jawab pendidikan disekolah tidak hanya dituntut memiliki kemampuan mengajar, tetapi teladan bagi anak didik sehingga di samping memiliki tingkat intelektual yang mumpuni juga memiliki kesadaran beragama yang baik. Karena ada 4 kompetensi yang harus dimiliki guru, yaitu 1) kompetensi pedagogik adalah tentang kemampuan guru dalam mengelola pembelajaran peserta didik seperti mengenal karakteristik siswa, menguasai teori belajar dan prinsip-prinsip pembelajaran, mengembangkan kurikulum, memahami dan mengembangkan potensi peserta didik, dan evaluasi pembelajaran. 2) kompetensi kepribadian adalah tentang kemampuan guru menjadi teladan yang baik bagi siswa, 3) kompetensi sosial adalah tentang kemampuan guru untuk bisa bermasyarakat dan bekerja sama dengan peserta didik serta guru-guru lainnya. 4) kompetensi profesional adalah kemampuan guru dalam mengikuti perkembangan ilmu terkini karena perkembangan ilmu selalu dinamis. (M. Gorky Sembiring, 2009: 39-40).

\section{METODE}

Pendekatan yang digunakan adalah pendekatan kualitatif. Pendekatan kualitatif ini dapat dipandang sebagai prosedur penelitian yang menghasilkan data deskriptif berupa kata-kata tertulis atau lisan dari orang-orang dan perilaku yang diamati. (Lexy J Moleong, 2002: 6).

Penelitian deskriptif adalah penelitian yang bermaksud untuk membuat pencandraan (deskripsi) mengenai situasi-situasi atau kejadian-kejadian. (Sumadi, 
2002: 18). Adapun tujuan penelitian deskriptif adalah untuk membuat pencandraan secara sistematis, faktual, dan akurat mengenai fakta-fakta dan sifat-sifat populasi atau daerah tertentu. Penelitian ini digunakan untuk mengetahui upaya guru pendidikan agama Islam dalam meningkatkan pemahaman keagamaan siswa di SMA Negeri 1 Tembilahan.

\section{Jenis Data}

1. Data primer

Data primer dalam penelitian adalah data yang menyangkut persoalan upaya guru pendidikan agama Islam dalam meningkatkan pemahaman keagamaan siswa di SMA Negeri 1 Tembilahan.

2. Data sekunder

Data sekunder adalah data yang diperoleh secara tidak langsung oleh peneliti, tapi telah berjenjang melalui sumber tangan kedua atau ketiga. Data sekunder dikenal sebagai data pendukung atau pelengkap data utama yang dapat digunakan oleh peneliti. Data sekunder dapat berupa gambar-gambar, dokumentasi, grafik, manuskrip, tulisan-tulisan tangan, dan dokumentasi lainnya.

3. Sumber data

Sumber data adalah sumber-sumber yang dimungkinkan seorang peneliti mendapatkan sejumlah informasi atau data-data yang dibutuhkan dalam sebuah penelitian. Sumber data dapat diperoleh dari lembaga atau situasi sosial, subjek, dokumentasi lembaga, badan atau histori.

\section{HASIL DAN PEMBAHASAN}

Secara bahasa guru diartikan sebagai "pendidik" atau orang yang mentransfer pengetahuan melalui proses belajar mengajar baik, formal, informal maupun non formal. Tidak hanya mentransfer pengetahuan tetapi juga membimbing, memotivasi mengarahkan dan menjadi teladan bagi peserta didik. Menurut Undang-Undang Sistem Pendidikan Nasional No. 20 tahun 2003 pasal 39 ayat 2, menjelaskan bahwa guru adalah tenaga profesional yang bertugas merencanakan dan melaksanakan pembelajaran, meneliti hasil pembelajaran, menilai hasil pembelajaran, melakukan pembimbingan dan pelatihan, serta melakukan penelitian 
dan pengabdian kepada masyarakat, Undang-Undang No. 20 Tahun (2003). Pengertian guru diartikan secara luas, yaitu "semua orang yang pernah memberikan ilmu atau kepandaian yang tertentu kepada seseorang atau kelompok orang.

Jadi, jika dilihat dari segi tempat tugas seorang guru bukan hanya bertugas di sekolah saja, melainkan di luar sekolah yaitu lingkungan masyarakat. Dengan demikian guru bukan hanya orang yang mengajar bidang studi saja, tetapi guru juga orang yang mendidik dan membantu murid dalam perkembangan jasmani dan rohaninya untuk mencapai kedewasaan.

\section{Kompetensi Guru Agama Islam}

Kompetensi adalah kewenangan atau kecakapan untuk menentukan atau memutuskan sesuatu hal. Maka kompetensi guru agama adalah kewenangan untuk menentukan pendidikan agama yang akan diajarkan pada jenjang tertentu di sekolah tempat guru itu mengajar. Adapun kompetensi guru pendidikan agama Islam dimaksudkan wewenang guru pendidikan agama Islam dalam memutuskan sesuatu sebagai upaya membantu siswanya menuju kepada kedewasaan.

Kompetensi merupakan pengetahuan, keterampilan dan nilai-nilai dasar yang direfleksikan dalam kebiasaan berpikir dan bertindak. Kebiasaan berpikir dan bertindak secara konsisten dan terus menerus memungkinkan seseorang menjadi kompeten, dalam arti memiliki pengetahuan, keterampilan dan nilai-nilai dasar untuk melakukan sesuatu.

Dengan demikian penulis menyimpulkan bahwa yang dimaksud dengan kompetensi guru pendidikan agama Islam adalah kecakapan guru pendidikan agama Islam dalam melaksanakan tugasnya dalam pengertian pemikiran, pengetahuan, keterampilan dan kemampuan dituntut oleh jabatan guru pendidikan agama Islam. Dalam Undang-Undang No. 14 Tahun 2005 tentang Guru dan Dosen, dijelaskan bahwa seorang guru wajib memiliki kompetensi pedagogik, kompetensi, kepribadian, kompetensi sosial, dan kompetensi profesional yang diperoleh melalui pendidikan profesi. Lebih khusus lagi ditegaskan Peraturan Pemerintah Republik Indonesia No. 55 tahun 2007 tentang Pendidikan Agama dan Keagamaan yaitu: "Guru mata pelajaran agama Islam harus memiliki kompetensi pedagogik, kepribadian, sosial, profesional, dan kepemimpinan". 
Sehubungan dengan macam kompetensi sebagaimana yang diuraikan, maka kompetensi guru mata pelajaran agama Islam, dapat dijabarkan sebagai berikut:

1. Kompetensi Pedagogik

Kompetensi pedagogik merupakan kemampuan guru dalam pengelolaan pembelajaran peserta didik yang sekurang-kurangnya meliputi:
a. Pemahaman wawasan kependidikan
b. Pemahaman terhadap peserta didik
c. Pengembangan kurikulum/silabus
d. Rancangan pembelajaran
e. Pelaksanaan pembelajaran yang mendidik dan dialogis
f. Pemanfaatan teknologi pembelajaran
g. Evaluasi hasil belajar
h. Pengembangan peserta didik untuk mengaktualisasikan berbagai potensi yang dimilikinya.

2. Kompetensi Kepribadian

Kompetensi kepribadian yang dimiliki seorang guru merupakan kemampuan personal yang mencerminkan kepribadian yang mantap, stabil, dewasa, arif dan berwibawa, menjadi teladan bagi peserta didik dan berakhlak mulia.

\section{Kompetensi Sosial}

Kompetensi sosial merupakan kemampuan yang dimiliki oleh guru sebagai bagian dari masyarakat yang sekurang-kurangnya meliputi kompetensi untuk:
a. Berkomunikasi, lisan, tulisan, atau isyarat
b. Mengusahakan teknologi komunikasi dan informasi secara fungsional
c. Bergaul secara efektif dengan peserta didik, sesama pendidik, tenaga kependidikan, orang tua/wali peserta didik
d. Bergaul secara santun dengan masyarakat sekitar.

4. Kompetensi Profesional

Kompetensi profesional adalah kemampuan menyusun materi pembelajaran secara luas dan mendalam sebagai inti pengembangan silabus 
serta kemampuan penguasaan materi pembelajaran secara luas dan mendalam. Oleh karena itu, kompetensi profesional yang dimiliki oleh seorang guru diharapkan mampu melaksanakan pendidikan secara efektif dan efisien.

5. Kompetensi Kepemimpinan

a. Kompetensi kepemimpinan merupakan salah satu kompetensi yang sangat penting dimiliki oleh seorang guru, khususnya guru mata pelajaran agama Islam meliputi:

b. Kemampuan membuat perencanaan pembudayaan pengalaman ajaran agama dan perilaku akhlak mulia pada komunitas sekolah sebagai bagian dari kegiatan pembelajaran agama.

c. Kemampuan mengorganisasikan potensi unsur sekolah secara sistematis untuk mendukung pembudayaan pengalaman ajaran agama pada komunitas sekolah.

d. Kemampuan menjadi inovator, motivator, fasilitator, pembimbing dan konselor dalam pembudayaan pengalaman ajaran agama pada komunitas sekolah.

e. Kemampuan menjaga, mengendalikan, dan mengarahkan pengalaman ajaran agama pada komunitas sekolah dan menjaga keharmonisan hubungan antar pemeluk agama dalam bingkai Negara Kesatuan Republik Indonesia.

Guru pendidikan agama Islam harus memiliki kemampuan dalam menjelaskan tujuan materi yang akan diajarkan kepada peserta didik, dan yang akan dikuasai peserta didik sebagai wujud hasil belajar peserta didik yang mengacu pada pengalaman langsung. Peserta didik perlu mengetahui tujuan belajar, dan tingkattingkat penguasaan yang akan digunakan sebagai kriteria pencapaian secara eksplisit, dikembangkan berdasarkan tujuan-tujuan yang telah ditetapkan, dan memiliki kontribusi terhadap kompetensi-kompetensi yang sedang dipelajari. Penilaian terhadap pencapaian hasil mengajar guru dilakukan secara objektif, berdasarkan penguasaan peserta didik terhadap pengetahuan, keterampilan, nilai dan sikap sebagai hasil capaian pembelajaran. 


\section{Fungsi Guru Agama}

Fungsi guru agama sebagai pekerjaan guru agama adalah membina seluruh kemampuan-kemampuan dan sikap-sikap yang baik dari murid sesuai dengan ajaran Islam. Hal ini berarti bahwa, perkembangan sikap dan kepribadian tidak terbatas pada pelaksanaannya melalui pembinaan di dalam kelas saja. Dengan kata lain, fungsi guru dalam membina siswa tidak terbatas pada interaksi belajar mengajar.

Fungsi sentral guru adalah mendidik. Fungsi sentral ini berjalan sejajar dengan atau dalam melakukan kegiatan mengajar (fungsi instruksional) dan kegiatan bimbingan, bahkan dalam setiap tingkah lakunya dalam berhadapan dengan muridnya (interaksi edukatif) senantiasa terkandung fungsi mendidik. Dari pada itu guru pun harus mencatat dan melaporkan pekerjaannya itu kepada berbagai pihak yang berkepentingan atau sebagai bahan yang dapat digunakannya sendiri untuk meningkatkan efektivitas pekerjaannya (sebagai umpan balik). Mengingat lingkup pekerjaan guru seperti yang dituliskan di atas, maka fungsi guru itu meliputi : Guru sebagai pengajar sepanjang sejarah kegunaan, tugas guru yang sudah tradisional adalah "mengajar". Sering orang salah duga, bahwa tugas guru hanyalah semata-mata mengajar. Bahkan masih banyak diantara para guru sendiri yang beranggapan demikian atau tampak masih dominan dalam karir sebagian besar guru, sehingga dua tugas lainnya menjadi tersisihkan atau terabaikan. Sebagai pengajar, guru bertugas membina perkembangan pengetahuan, sikap dan keterampilan.

Guru sebagai pembimbing dan pemberi bimbingan adalah dua macam peranan yang mengandung banyak perbedaan dan persamaannya. Keduanya sering dilakukan oleh guru yang ingin mendidik dan yang bersikap mengasihi dan mencintai siswa. Bagi guru agama meliputi bimbingan belajar dan bimbingan perkembangan sikap keagamaan. Dengan demikian membimbing dan pemberian bimbingan dimaksudkan agar setiap murid diinsafkan mengenai kemampuan dan potensi diri murid yang sebenarnya dalam kapasitas belajar dan bersikap.

Guru bertugas pula sebagai tenaga administrasi, bukan berarti sebagai pegawai kantor, melainkan sebagai pengelola kelas atau pengelola (manager) 
interaksi belajar mengajar. Meskipun masalah pengelolaan ini dapat dipisahkan dari masalah mengajar dan bimbingan, tetapi tidak seluruhnya dapat dengan mudah diidentifikasi. Sesungguhnya ketiga hal itu saling berhubungan dan tidak terpisahkan dari mengajar itu sendiri. Ketiga tugas itu dilaksanakan sejalan secara seimbang dan serasi. Tidak boleh ada satu pun yang terabaikan, karena semuanya fungsional dan saling berkaitan dalam menuju keberhasilan pendidikan sebagai suatu keseluruhan yang tidak terpisahkan. Dengan demikian dapat diharapkan dari padanya untuk mengerahkan segala kemampuan dan keterampilannya dalam mengajar secara profesional dan efektif .

Berdasarkan pasal 30 Bab VI ayat 2 Undang-Undang Sistem Pendidikan Nasional No. 20 tahun 2003, bahwa pendidikan agama berfungsi mempersiapkan peserta didik menjadi anggota masyarakat memahami dan mengamalkan nilai-nilai ajaran agamanya dan/atau menjadi ilmu agama. Menurut Zakiah Darajat pendidikan agama Islam adalah bimbingan dan asuhan terhadap anak didik agar kelak setelah selesai pendidikannya dapat memahami dan mengamalkan ajaran agama Islam serta menjadikannya sebagai pandangan hidup (way of life). (Zakiah Darajat, dkk 2009: 86).

Pendidikan agama Islam adalah upaya sadar dan terencana dalam menyiapkan peserta didik untuk mengenal, memahami, menghayati, mengimani, bertakwa berakhlak mulia, mengamalkan ajaran agama Islam dari sumber utamanya kitab suci Al-Quran dan Al-Hadits, melalui kegiatan bimbingan, pengajaran latihan, serta penggunaan pengalaman.

Menurut KPPN (Komisi Pembaharuan Pendidikan Nasional) agama mempunyai peranan yang penting dalam kehidupan manusia Pancasila sebab agama merupakan motivasi hidup dan kehidupan serta merupakan alat pengembangan dan pengendalian diri yang amat penting. Oleh karena itu agama perlu diketahui, dipahami, dan diamalkan oleh manusia Indonesia agar dapat menjadi dasar kepribadian sehingga ia dapat menjadi manusia yang utuh. Agama mengatur hubungan manusia dengan Tuhan Yang Maha Esa, hubungan manusia dengan manusia, hubungan manusia dengan alam dan hubungan manusia dengan dirinya yang dapat menjamin keselarasan, keseimbangan, dan keserasian dalam 
hidup manusia, baik sebagai pribadi maupun sebagai anggota masyarakat dalam mencapai kemajuan lahiriah dan kebahagiaan rohaniah.

Oleh karena agama sebagai dasar tata nilai merupakan penentu dalam perkembangan dan pembinaan rasa kemanusiaan yang adil dan beradab, maka pemahaman dan pengalamannya dengan tepat dan benar diperlukan untuk menciptakan kesatuan bangsa. Bahan pendidikan agama bagi masing-masing pemeluknya berasal dari sumber-sumber agamanya. Pelaksanaan pendidikan agama dilakukan oleh pengajar yang meyakini, mengamalkan, dan menguasai bahan agama tersebut. Dan salah satu tujuan pendidikan nasional adalah meningkatkan ketakwaan terhadap Tuhan Yang Maha Esa. Untuk mencapai tujuan, pendidikan agama perlu diberikan pada semua jenjang dan jenis sekolah dan dimasukkan ke dalam kurikulum sekolah tingkat dasar sampai dengan tingkat tinggi.

Pendidikan agama merupakan bagian pendidikan yang amat penting yang berkenaan dengan aspek-aspek sikap dan nilai, antara lain akhlak dan keagamaan. Oleh karena itu, pendidikan agama juga menjadi tanggung jawab keluarga, masyarakat dan pemerintah. Untuk menjamin tercapainya tujuan pendidikan nasional, dalam pendidikan agama diperlukan: (a) paket-paket minimal bahan pendidikan agama dari masing-masing agama yang dianut dengan mempertimbangkan perkembangan jiwa anak didik; (b) guru agama yang cukup memenuhi syarat; (c) prasarana dan sarana pendidikan agama yang cukup dan memenuhi syarat; (d) lingkungan yang mendorong tercapainya tujuan pendidikan agama, di antaranya situasi sekolah, masyarakat dan perundang-undangan. Pendidikan agama dan pendidikan penghayatan serta pengamalan Pancasila harus saling menunjang karena sama-sama bidang sikap dan nilai dalam rangka pengembangan bangsa. Meskipun demikian, perlu diadakan pembedaan yang jelas antara keduanya karena adanya perbedaan bahan ajar dan peserta didik. (Zakiah Darajat, dkk. 2009: 86-88).

Pendidikan agama Islam adalah pendidikan dengan melalui ajaran-ajaran agama Islam, yaitu berupa bimbingan dan asuhan terhadap anak didik agar nantinya setelah selesai dari pendidikan ia dapat memahami, menghayati dan mengamalkan 
ajaran-ajaran agama Islam yang telah diyakininya secara menyeluruh, serta menjadikan ajaran agama Islam itu sebagai suatu pandangan hidupnya demi keselamatan dan kesejahteraan hidup di dunia maupun di akhirat kelak.

Dari pengertian di atas, penulis berkesimpulan bahwa pendidikan agama Islam adalah upaya sadar dan terencana dalam menyiapkan peserta didik untuk mengenal, memahami, menghayati, hingga mengimani, ajaran agama Islam, dibarengi dengan tuntunan untuk menghormati penganut agama lain dalam hubungannya dengan kerukunan antar umat beragama hingga terwujud kesatuan dan persatuan bangsa.

Tujuan pendidikan Islam merupakan hal yang dominan dalam pendidikan, rasanya penulis perlu mengutip ungkapan breiter, bahwa pendidikan adalah persoalan tujuan dan fokus. Mendidik anak berarti bertindak dengan tujuan agar mempengaruhi perkembangan anak sebagai seseorang secara utuh. Pendidikan agama Islam di sekolah bertujuan untuk menumbuhkan dan meningkatkan keimanan melalui pemberian dan pemupukan pengetahuan, penghayatan, pengamalan, serta pengalaman peserta didik tentang agama Islam sehingga menjadi manusia muslim yang terus berkembang dalam hal keimanan, ketakwaannya, berbangsa dan bernegara, serta untuk dapat melanjutkan pada jenjang pendidikan yang lebih tinggi.

Secara umum, tujuan pendidikan agama Islam terbagi kepada: tujuan umum, tujuan sementara, tujuan akhir, dan tujuan operasional, tujuan umum adalah tujuan yang akan dicapai dengan semua kegiatan pendidikan baik dengan pengajaran atau dengan cara lain. Tujuan sementara adalah tujuan yang akan dicapai setelah anak didik diberi sejumlah pengalaman tertentu yang direncanakan dalam sebuah kurikulum. Tujuan akhir adalah tujuan yang dikehendaki agar peserta didik manusia-manusia yang sempurna (insan kamil). Sedangkan tujuan operasional adalah tujuan praktis yang akan dicapai dengan sejumlah kegiatan pendidikan tertentu.

Tujuan pendidikan agama Islam dalam perspektif para ulama muslim. 1) Menurut Abdul Rahman Shaleh mengatakan bahwa pendidikan Islam bertujuan untuk membentuk kepribadian sebagai khalifah Allah SWT., sekurang-kurangnya 
mempersiapkan diri kepada tujuan akhir, yakni beriman kepada Allah dan tunduk serta patuh secara total kepadanya. 2) Menurut Imam Al-Gazali mengatakan ada dua tujuan utama yakni, membentuk insan purna yang pada akhirnya dapat mendekatkan diri kepada Allah swt. Dan membentuk insan sempurna untuk memperoleh kebahagiaan dunia maupun akhirat. 3) Menurut Hasan Lagulung dalam bukunya asas-asas pendidikan Islam, hasan lagulung menjelaskan, bahwa tujuan pendidikan harus dikaitkan dengan tujuan hidup manusia, atau lebih tegasnya, tujuan hidup untuk menjawab persoalan, untuk apa kita hidup yakni semata-mata hanya untuk menyembah kepada Allah SWT.

Dari beberapa pendapat di atas tujuan pendidikan Islam dapat disimpulkan bahwa tujuan pendidikan Islam adalah sesuatu yang diharapkan tercapai setelah proses pendidikan berakhir. Tujuan ini diklasifikasikan kepada: tujuan umum, tujuan sementara, tujuan akhir dan tujuan operasional. Banyak sekali konsep dan teori tujuan pendidikan Islam yang telah dikemukakan oleh para ahli pendidikan, baik pada zaman klasik, pertengahan maupun dewasa ini. Namun dapat dipahami, bahwa beragamnya konsep dan teori tujuan pendidikan agama Islam tersebut merupakan bukti adanya usaha dari para intelektual muslim dan masyarakat muslim umumnya untuk menciptakan suatu sistem pendidikan yang baik bagi masyarakatnya. Namun demikian berkembangnya pemikiran tentang tujuan pendidikan Islam tidak pernah melenceng dari prinsip dasar yang menjadi asas berpijak dalam pengembangan tujuan pendidikan yang dimaksud.

Oleh karena itu berbicara pendidikan agama Islam, baik makna maupun tujuannya haruslah mengacu pada penanaman nilai-nilai Islam dan tidak dibenarkan melupakan etika sosial atau moralitas sosial. Penanaman nilai-nilai ini juga dalam rangka menuai keberhasilan hidup di dunia bagi anak didik yang kemudian akan mampu membuahkan kebaikan di akhirat kelak.

Fungsi Pendidikan Agama Islam di sekolah adalah: 1) meningkatkan keimanan dan ketakwaan peserta didik kepada Allah Swt. yang telah ditanamkan dalam lingkungan keluarga. Pada dasarnya kewajiban menanamkan keimanan dan ketakwaan di lakukan oleh setiap orang tua dalam keluarga. Sekolah berfungsi untuk menumbuh kembangkan lebih lanjut dalam diri anak melalui bimbingan, 
pengajaran dan pelatihan agar keimanan dan ketakwaan tersebut dapat berkembang secara optimal sesuai dengan tingkat perkembangannya. 2) Penanaman nilai, sebagai pedoman hidup untuk mencari kebahagiaan hidup didunia dan di akhirat. 3) Penyesuaian mental, yaitu untuk menyesuaikan diri dengan lingkungannya baik lingkungan fisik maupun lingkungan sosial dan dapat mengubah lingkungannya sesuai dengan ajaran agama Islam. 4) Perbaikan, yaitu untuk memperbaiki kesalahan-kesalahan, kekurangan-kekurangan dan kelemahan-kelemahan peserta didik dalam keyakinan, pemahaman dan pengalaman ajaran dalam kehidupan sehari-hari. 5) Pencegahan, yaitu untuk menangkal, hal-hal negatif dari lingkungannya atau dari budaya lain yang dapat membahayakan dirinya dan menghambat perkembangannya menuju manusia Indonesia seutuhnya. 6) Pengajaran, tentang ilmu pengetahuan keagamaan secara umum sistem dan fungsional. 7) Penyaluran, yaitu untuk menyalurkan anak-anak yang memiliki bakat khusus di bidang agama Islam agar bakat tersebut dapat berkembang secara optimal sehingga dapat dimanfaatkan untuk dirinya sendiri dan bagi orang lain.

Oleh karena itu, pendidikan agama Islam sangat penting sebab dengan pendidikan agama Islam, orang tua atau guru berusaha secara sadar memimpin dan mendidik anak diarahkan kepada perkembangan jasmani dan rohani sehingga mampu membentuk kepribadian yang utama yang sesuai dengan ajaran agama Islam.

Pendidikan agama Islam hendaknya ditanamkan sejak kecil, sebab pendidikan pada masa kanak-kanak merupakan dasar yang menentukan untuk pendidikan selanjutnya. Sebagaimana menurut pendapat Zakiyah Drajat bahwa: "pada umumnya agama seseorang ditentukan oleh pendidikan, pengalaman dan latihan yang dilaluinya sejak kecil”. Selaras dengan pendidikan nasional yang bertujuan untuk mengarahkan potensi peserta didik agar menjadi manusia yang beriman dan bertakwa kepada tuhan yang maha esa, berakhlak mulia, sehat, berilmu, cakap, kreatif, mandiri, dan menjadi warga Negara yang demokratis serta bertanggung jawab. 


\section{Pemahaman Keagamaan Siswa}

Pada umumnya pemahaman agama seseorang secara konkret ditentukan oleh pengalaman, pendidikan dan pergaulannya semenjak kecil dalam hidupnya seharihari. Pengalaman dalam lingkungan rumah tangga merupakan peletak dasar dalam pertumbuhan dan perkembangan agama pada setiap anak. Hal ini kelak akan berlanjut dalam pendidikannya di sekolah, sehingga pendidikan agama di lingkungan keluarga mempunyai peranan penting dan sangat menentukan. (Nurwanita Z, 2007: 39).

Perkembangan agama pada anak sangat ditentukan oleh pendidikan dan pengalaman yang dilaluinya, terutama pada masa-masa pertumbuhan yang pertama (masa anak) dari umur 0-112 tahun. Seorang anak yang pada masa anak itu tidak mendapat didikan agama dan tidak pula mempunyai pengalaman keagamaan, maka ia nanti setelah dewasa akan cenderung kepada sikap negatif terhadap agama. (Zakiyah Darajat, 2005: 9).

Zakiyah Darajat menyebutkan "seseorang yang pada waktu kecilnya tidak pernah mendapatkan didikan agama, maka pada waktu dewasanya nanti ia tidak akan merasakan pentingnya agama dalam hidupnya". (Nurwanita Z, 2007: 40).

Pendapat di atas menunjukkan betapa besar pengaruh pendidikan agama di lingkungan rumah tangga yang menjadi pusat kehidupan rohani bagi si anak. Anakanak dalam lingkungan rumah tangga menerima agama dari orang tuanya, oleh karena itulah maka peranan orang tua besar sekali dalam pertumbuhan dan perkembangan agama pada masa anak-anak.

Peranan orang tua dalam menumbuhkan jiwa agama bagi anaknya, memberikan prospek kehidupan anak pada masa yang akan datang. Orang tua yang mengerti tentang urgensi pertumbuhan dan perkembangan agama dalam kehidupan anak akan memberikan suatu kecenderungan kepada aturan-aturan agama yang harus dilaksanakan dalam praktik hidupnya sehari-hari. Hal seperti inilah dapat dimanfaatkan untuk melatih anak dalam membiasakan menjalankan ibadah agama dengan rasa disiplin dan tanggung jawab.

Proses perkembangan jiwa agama pada masa anak-anak ditanamkan oleh kedua orang tua melalui beberapa kesempatan pergaulan sebagai berikut: 
1. Dalam permainan

2. Dalam latihan-latihan/praktek kerja sehari-hari

3. Melalui perintah orang tua

4. Memberikan contoh teladan dan pembiasaan disiplin

5. Melalui cerita-cerita, baik cerita kepahlawanan maupun cerita agama dan sebagainya.

Proses perkembangan naluri beragama akan dapat berjalan sesuai dengan pertumbuhan fisik anak. Dampak jiwa agama dalam sikap dan tingkah lakunya dalam kehidupan sehari-hari, cenderung mengadaptasikan dirinya dengan lingkungan sekitarnya. Di dalam ajaran agama Islam terdapat ajakan untuk menyuruh diri sendiri dan keluarga, sebagaimana firman Allah SWT.

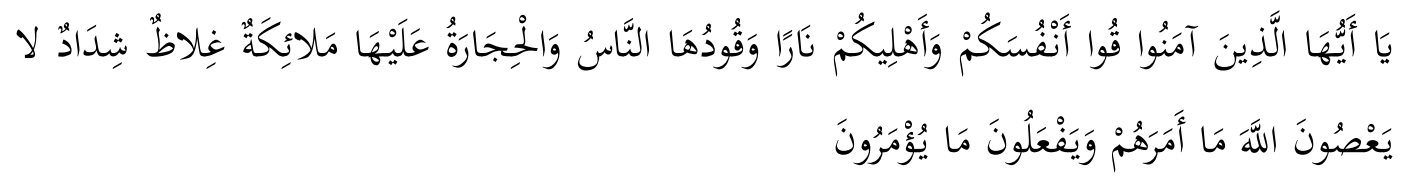

Artinya: Hai orang-orang yang beriman, peliharalah dirimu dan keluargamu dari api neraka yang bahan bakarnya adalah manusia dan batu; penjaganya malaikat-malaikat yang kasar, keras, dan tidak mendurhakai Allah terhadap apa yang diperintahkan-Nya kepada mereka dan selalu mengerjakan apa yang diperintahkan (Q.S. At-Tahrim: 6).

Ayat di atas memberikan tuntunan agar manusia dapat memelihara diri, keluarga serta anak dari siksa api neraka. Adapun cara memeliharanya adalah dengan mendidik, mencerdaskan dan mengajarinya akhlak yang baik, juga menjaganya dari teman-teman yang berakhlak buruk. Tidak dibiasakan hidup dengan kesenangan, tidak pula diajarkan mencintai perhiasan dunia, dan sebabsebab kemewahan lainnya. Sebab, dengan berbuat itu maka sama saja ia telah menyia-nyiakan umurnya di dalam mencari kemewahan. Dan apabila sang anak telah menjadi dewasa, ia akan menjadi binasa untuk selama-lamanya. Akan tetapi, seyogianyalah ia diawasi sejak dari permulaan atau pertama. (Al-Ghazali, 2012: 260).

Memelihara diri dan keluarga adalah membutuhkan sikap keteladanan dan perhatian yang kontinu, tidak cepat putus asa, lemah semangat dan sebagainya. Apa yang telah dipercayai oleh anak, tergantung kepada apa yang diterima dari kedua 
orang tuanya di rumah, dan atau guru di sekolah serta apa yang telah dilihat dan dirasakan di lingkungan masyarakatnya. Anak menerima agama secara global, sebab masih belum mampu berpikir logis. Penerimaan tersebut adalah karena mengikuti kehendak orang tuanya. Kepercayaan agama bagi anak akan lebih mudah tertanam pada jiwa anak, apabila melalui cerita-cerita atau dongeng-dongeng orang sakti, cerita agama atau cerita nenek moyang dahulu, serta kisah-kisah tokoh agama. ( Nurwanita Z, 2007: 43).

Kepercayaan agama bagi anak-anak akan bertambah lagi, melalui latihanlatihan dan didikan yang terima dalam lingkungannya. Biasanya kepercayaan itu berdasarkan konsepsi-konsepsi yang nyata dan konkret, sehingga anak tersebut mudah mengasosiasikannya dengan kehidupan sehari-hari. Anak-anak tersebut menerima agama berdasarkan gambaran yang pernah dilihat dan didengar. Potensi keagamaan yang ada pada diri setiap anak, akan berkembang sesuai dengan pertumbuhan dan perkembangan fisik dan psikisnya. Semakin besar anak tersebut, maka akan semakin jelas dan paham akan ajaran agama yang dilakukannya itu, dengan demikian pertumbuhan dan perkembangan jiwa agama bagi anak-anak semakin sempurna.

Sesungguhnya pertumbuhan dan perkembangan jiwa agama bagi anak sedikit demi sedikit menjadi lebih aktual, yang menyebabkan pengertian anak terhadap manfaat agama akan mendapatkan lapangan baru dalam dirinya. Bertambahnya pengertian mereka, akan muda pula menimbulkan perhatian yang serius dan terfokus sehingga agama bagi anak memberikan motivasi dan gairah dalam praktik hidup sehari-hari. Tidak heran apabila ada anak yang selalu mempertahankan diri pribadinya, karena apa yang menjadi pegangan hidupnya baik karena hasil didikan maupun karena pengaruh bahkan dan situasi lingkungannya.

Apabila agama telah mendapatkan tempat yang terhormat di hati anak, maka sudah tentu segala ucapan, perbuatan dan tingkah lakunya akan menjurus kepada sifat-sifat yang terpuji, dengan demikian akan terlihat bahwa perkembangan perasaan agama bagi anak akan semakin tinggi, sesuai dengan ketinggian agama yang dianutnya. Allah semakin dekat kepada jiwa anak, manakala anak tersebut juga semakin dekat pula kepada Allah. Ia mulai mendengar kata hatinya tentang 
akhlak, dan Allah menjadi pantulan dari suara hatinya. Hal ini telah dikemukakan dalam filsafat yang menganggap bahwa moral-lah yang merupakan jalan untuk menyampaikan kepada Allah.

Berdasarkan penjelasan di atas maka dapat disimpulkan bahwa pada umumnya perkembangan agama seseorang secara konkret ditentukan oleh pengalaman, pendidikan dan pergaulannya semenjak kecil dalam kehidupan seharihari, baik itu pengalaman dalam keluarga, lingkungan masyarakat maupun lingkungan sekolah.

Pengetahuan agama di waktu kecil, akan membawa pengertian hakikat agama setelah ia sudah remaja. Pengertian tentang agama yang seperti inilah yang mendorong anak untuk selalu memperdalam ajaran agama yang diterimanya.

Sebagaimana yang telah diketahui bahwa pertumbuhan agama akan selalu berhubungan dengan pertumbuhan fisik dan psikisnya (intelegensi), sehingga remaja kadang-kadang memperlihatkan sifat fanatik dan menunjukkan sikap emosinya yang tinggi. Akan tetapi, kadang-kadang pula remaja menentang dan menjauhkan dirinya dari agama, akibat karena perasaannya yang belum stabil serta pertumbuhan organ tubuh dan kelenjarnya yang belum sempurna.

Berbicara pertumbuhan jasmani dan rohani remaja, maka jelas tidak dapat dipisahkan dengan pertumbuhan dengan perkembangan jiwa agamanya. Para psikolog meletakkan dasar penentuan pertumbuhan dan perkembangan agama. Ditinjau dari segi umur remaja. Menurut Alfret Binnet, seseorang psikolog Perancis yang terkenal dengan mental test-nya, mengatakan bahwa pada umur 14 tahun usia remaja sering kali menolak hal-hal yang kurang/tidak masuk akalnya, dan kadangkadang menolak sesuatu yang dahulu sudah pernah diterimanya. Timbul perasaan membandel, membantah, bahkan dia mengkritik dan tidak mau mengalah. Remaja tidak sabar sehingga dia bertindak keras/kasar dan kadang-kadang melanggar nilainilai/norma-norma agama dan moral atau menentang nilai-nilai/norma-norma masyarakat.

Kebutuhan remaja akan agama sebagai pasangan hidup dapat membantu mereka dalam membatasi dorongan-dorongan yang semakin mendesak. Remaja yang hidup dan di besarkan dalam lingkungan keluarga yang aman dan tenteram, 
tekun beribadah akan menampakkan keyakinannya terhadap Allah. Salah satu yang perlu diingat bahwa pengertian mereka akan pokok ajaran agama dapat mempengaruhi perkembangan pikiran yang sedang mereka alami dan akan dilakukannya. Gambaran remaja terhadap adanya Allah SWT dengan sifat-sifatnya merupakan bagian dari gambaran terhadap alam lingkungannya, serta dipengaruhi pula oleh perasaan dan sifat remaja itu sendiri.

Kepercayaan remaja akan kekuasaan Allah, akan menyebabkan munculnya rasa tanggung jawab baik kepada Allah maupun kepada masyarakat. Demikian pula sebaliknya apabila remaja itu diliputi perasaan kekecewaan dalam hidupnya, maka akan dapat menimbulkan kontradiksi dalam perasaannya, sehingga mungkin efeknya berakibat kepada menjauhi Allah atau menentang adanya kekuasaan Allah swt. Hal ini tampak sekali pada perbedaan antara nilai-nilai ajaran agama yang diterimanya dengan sikap dan perlakuan orang dalam masyarakat dalam menjalankan ajaran agama.

Perbedaan di atas menyebabkan kegelisahan bagi remaja, kadang-kadang menimbulkan perasaan benci kepada mereka, bahkan yang lebih fatal lagi apabila perbedaan pendapat tersebut, justru remaja membenci agama yang dianutnya.

Maka dengan demikian akan timbul asumsi bahwa semakin merosotnya moral dalam masyarakat, akan semakin gelisah remajanya dan sebaliknya pula merosotnya jiwa remaja akan mendatangkan keresahan dalam masyarakat. Pengalaman para remaja dapat menunjukkan adanya beberapa sikap remaja terhadap agama, yaitu sebagai berikut:

1. Remaja menerima agama secara global

2. Remaja menerima agama dengan perasaan acuh tak acuh

3. Membantah dan diiringi dengan sikap kritis

4. Menerima agama dengan ragu-ragu

5. Melaksanakan agama dengan keyakinan.

Pada hakikatnya sikap remaja didasari oleh perasaan yang tidak dominan terhadap ajaran agama. Kadang-kadang cinta dan sangat percaya sama Allah, akan tetapi kadang-kadang pula menjadi acuh tak acuh dan menentang adanya Allah SWT. 
Perasaan inilah yang disebut dengan perasaan ambivalen. Dalam suasana seperti inilah remaja memerlukan pembinaan motivasi agama terpadu dalam lingkungan keluarga di rumah tangga, guru atau pendidik di sekolah dan pemimpin atau tokoh-tokoh masyarakat. Pembinaan dan motivasi agama ini harus dapat melalui:

1. Latihan-latihan agama, supaya dapat menjadi kebiasaan

2. Tradisi agama yang akan dapat menjadi norma/ aturan hidup

3. Penanaman contoh teladan, sehingga dapat menjadi panutan

4. Aktivitas agama lainnya.

Pembinaan dan motivasi agama diharapkan akan dapat membentuk kebiasaan hidup beragama, yang akan memberi corak dan warna tingkah laku dalam kehidupan sehari-hari. Dan bertitik tolak dalam kebiasaan ini, akan menjadi norma dan aturan hidup sehingga dapat diharapkan akan membudaya di kalangan remaja. Jadi dapat disimpulkan bahwa untuk membentuk perilaku peserta didik diperlukan suatu pembinaan dan motivasi serta pengarahan dari pendidik untuk membentuk kebiasaan dalam hidup beragama. Fitrah keagamaan atau kecenderungan hidup beragama sebenarnya sudah ada sejak lahir, potensi beragama setiap anak harus dikembangkan oleh orang tua masing-masing, dengan melalui pendidikan dan latihan. Perubahan perilaku anak seiring dengan bertambahnya usia, latihan, pembiasaan, pengalaman yang diperolehnya baik dari diri anak maupun lingkungan, sehingga akan terbentuk suatu sikap kuat untuk mendalami pelajaran agama dalam dirinya.

\section{Bentuk-bentuk perilaku keagamaan}

1. Pembentukan kebiasaan bersikap dan berperilaku sesuai dengan tuntutan akhlakkul karimah yang dicontohkan Rasulullah saw., seperti mengucapkan atau menjawab salam kepada sesama teman di sekolah, berdoa bersama sebelum memulai dan sesudah selesai kegiatan belajar mengajar, mendoakan teman atau anggota keluarganya yang sakit, atau yang sedang tertimpa musibah, bersikap santun dan rendah hati, saling menghormati dan menolong antar sesama, dan semacamnya. Selain itu, unsur keteladanan dan suasana lingkungan memegang peranan utama dalam pembentukan kebiasaan, dengan demikian 
melalui pemahaman, keteladanan dan lingkungan yang selaras dengan petunjuk agama, siswa akan terdorong untuk membentuk dirinya menjadi seorang muslim. Adapun pembentukan kebiasaan meliputi:

a. Kebiasaan untuk berbuat ihsan terhadap Allah Swt.

b. Kebiasaan berbuat ihsan terhadap sesama manusia

c. Kebiasaan berbuat ihsan terhadap makhluk Allah lainnya, Zakiah Darajat, dkk. (2009: 193-194).

2. Melaksanakan kegiatan-kegiatan yang bersifat religius, seperti:

a. Shalat Dhuha dan Shalat dhuhur berjamah untuk meningkatkan disiplin ibadah dan memperdalam rasa kebersamaan dan persaudaraan antar sesama muslim. Sesudah salat dhuhur diupayakan diadakan kultum (kuliah tujuh menit) untuk melatih siswa mengemukakan pokok-pokok pikirannya tentang nilai dan norma agama Islam yang menjadi panutan dan bimbingan perilaku setiap hari.

b. Mengumpulkan zakat, infak dan sedekah, mengumpulkan pakaian bekas seragam sekolah atau pakaian bekas lainnya, mengumpulkan buku-buku bekas yang tidak terpakai untuk diberikan kepada fakir miskin, anak yatim piatu, dan orang lain yang membutuhkan. Kegiatan ini bermanfaat untuk membina perilaku dan peduli antar sesama yang secara ekonomi kurang beruntung.

c. Melaksanakan pesantren Ramadhan dan pesantren kilat untuk memberikan tambahan pengetahuan dan pemahaman tentang nilai dan norma Islam yang dilaksanakan pada bulan Ramadhan dan liburan panjang. Program ini akan mencapai keberhasilan apabila disiapkan secara matang dengan mendayagunakan semua sumber daya yang tersedia di sekolah dan lingkungan sekitarnya.

d. Melaksanakan peringatan hari-hari besar Islam untuk meningkatkan dakwah dan wawasan siswa tentang sejarah, nilai dan norma agama Islam yang berkembang di masa lalu, masa kini dan masa yang akan datang. Kegiatan ini sebaiknya dilakukan dengan mengadakan kerja sama dengan 
lembaga-lembaga Islam yang berada di sekitar sekolah, seperti mesjid, pondok pesantren, pusat-pusat studi Islam dan semacamnya.

e. Melatih peserta didik untuk memiliki kebiasaan tolong menolong dalam kehidupan sehari-hari seperti meminjamkan pensil, penghapus, kepada teman yang sedang membutuhkan.

\section{KESIMPULAN}

Dari pengertian guru di atas dapat diambil suatu kesimpulan bahwa guru bukanlah sekedar pemberi ilmu pengetahuan kepada anak didiknya di depan kelas, tetapi merupakan tenaga profesional yang di samping memperlihatkan aspek kognitif juga aspek psikomotorik dan efektif pada anak didik agar tumbuh dan terbina secara utuh sebagai manusia-manusia yang berpribadi sehingga maksud mendidik untuk mengantarkan peserta didik menuju ke arah kedewasaan dapat tercapai.

Juga dapat disimpulkan bahwa pemahaman keagamaan itu sangat diperlukan untuk melatih peserta didik agar selalu mengingat dan melaksanakan segala perintah Allah dan menjauhi segala larangan-Nya. Karena dalam agama ada ajaranajaran yang dilakukan bagi pemeluk-pemeluknya, bagi agama Islam, ada ajaran yang harus dilakukan dan ada pula yang berupa larangan. Ajaran-ajaran yang berupa perintah yang harus dilakukan di antaranya adalah Shalat, zakat, puasa, haji, menolong orang lain yang kesusahan dan masih banyak lagi. Sedangkan yang ada kaitannya dengan larangan itu lagi banyak seperti, minum-minuman keras, judi, korupsi, main perempuan dan lain-lain. Oleh sebab itu secara tidak langsung aktivitas yang dilakukan dalam kehidupan sehari-hari baik itu yang ada hubungannya antara makhluk dengan pencipta, maupun hubungan antara makhluk dengan sesama makhluk, pada dasarnya sudah diatur oleh agama.

Hasil penelitian ini menunjukkan telah dilaksanakan dengan baik kecuali kurangnya ketersediaan sarana prasarana dan waktu pembelajaran dalam mengoptimalkan pemahaman agama siswa. 
Upaya Guru Pendidikan Agama Islam dalam Meningkatkan Pemahaman .......

\section{REFERENSI}

Ahmad, T. (2002). Ilmu Pendidikan dalam Perspektif Islam. Bandung: Remaja Rosda Karya.

Al-Ghazali. (2012). Ihya Ulumuddin "Menghidupkan Kembali Ilmu-ilmu Agama”. Jakarta: Republika.

Chabib, T, dkk. (2009). Metodologi Pengajaran Agama. Yogyakarta: Pustaka Pelajar.

M. Gorky Sembiring. (2009). Mengungkap Rahasia dan Tips Manjur Menjadi Guru Sejati. Yogyakarta: Best Publisher

Moleong. L. J. (2002). Metodologi Penelitian Kualitatif. Bandung: PT. Remaja Rosda Karya.

Nurwanita, Z. (2007). Psikologi Agama “Pendekatan Islam”. Makassar: LP4.

Sumadi, S. (2002). Metodologi Penelitian. Jakarta: PT Raja Grafindo Persada.

Undang-Undang No. 20 Tahun 2003 Sistem Pendidikan Nasional. (2003).

Undang-undang No. 20 tahun 2003 tentang Sistem Pendidikan Nasional Republik Indonesia (2003).

Zakiah, D. (2009). Ilmu Pendidikan Islam. Jakarta: Bumi Aksara.

Zakiyah, D. (2005). Ilmu Jiwa Agama, Jakarta: Bulan Bintang.

Zuhairini. (1994). Sejarah Pendidikan Islam. Jakarta: Aksara. 